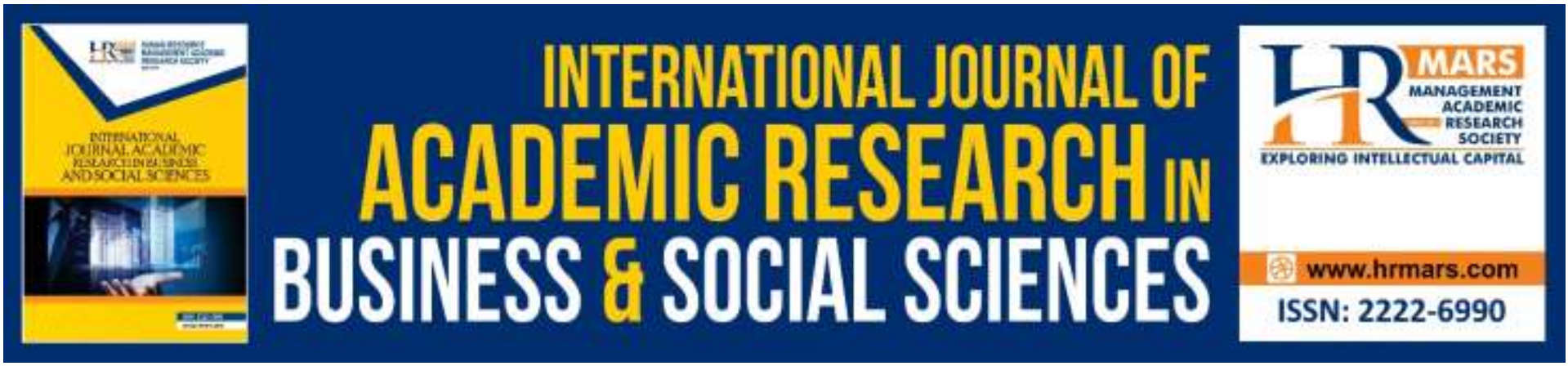

\title{
Government Debt: An Empirical Analysis with Structural Break for The Economy of Malaysia
}

Shairil Izwan Taasim, Adrian Daud, Saizal Pinjaman, Mohamad Ibrani Shahrimin Bin Adam Assim, Yasmin Binti Yaccob

To Link this Article: http://dx.doi.org/10.6007/IJARBSS/v11-i17/11396 DOI:10.6007/IJARBSS/v11-i17/11396

Received: 06 August 2021, Revised: 03 September 2021, Accepted: 23 September 2021

Published Online: 17 October 2021

In-Text Citation: (Taasim et al., 2021)

To Cite this Article: Taasim, S. I., Daud, A., Pinjaman, S., Assim, M. I. S. B. A., \& Yaccob, Y. B. (2021).

Government Debt: An Empirical Analysis with Structural Break for The Economy of Malaysia. International Journal of Academic Research in Business and Social Sciences, 11(17), 120-126.

Copyright: (c) 2021 The Author(s)

Published by Human Resource Management Academic Research Society (www.hrmars.com)

This article is published under the Creative Commons Attribution (CC BY 4.0) license. Anyone may reproduce, distribute, translate and create derivative works of this article (for both commercial and non-commercial purposes), subject to full attribution to the original publication and authors. The full terms of this license may be seen

at: http://creativecommons.org/licences/by/4.0/legalcode

Special Issue Title: Empowering Community and Beyond, iRandau, 2021, Pg. 120 - 126

Full Terms \& Conditions of access and use can be found at http://hrmars.com/index.php/pages/detail/publication-ethics 


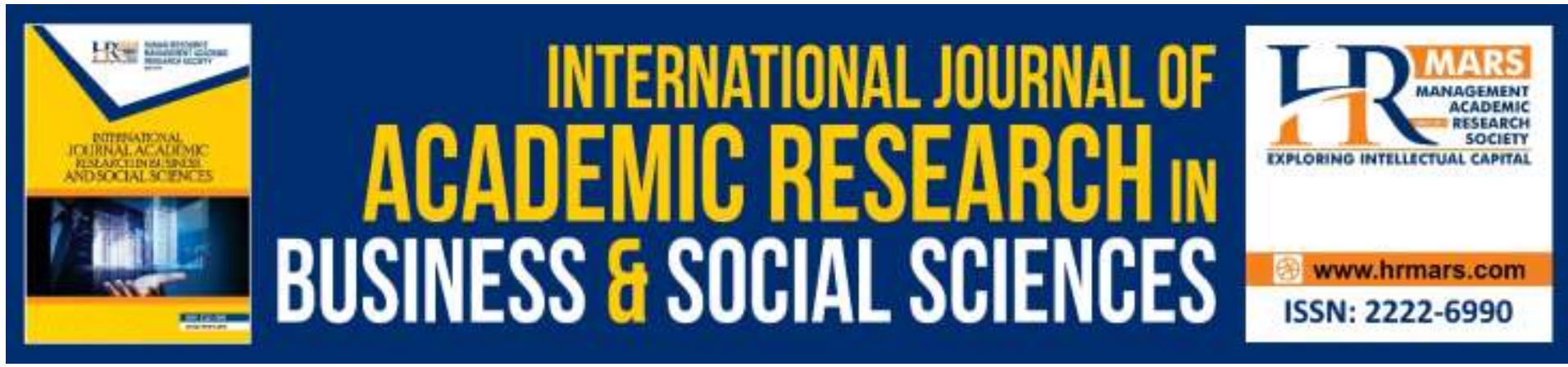

\title{
Government Debt: An Empirical Analysis with Structural Break for The Economy of Malaysia
}

\author{
${ }^{1}$ Shairil Izwan Taasim, ${ }^{1}$ Adrian Daud, ${ }^{2}$ Saizal Pinjaman, \\ ${ }^{1}$ Mohamad Ibrani Shahrimin Bin Adam Assim, ${ }^{1}$ Yasmin Binti \\ Yaccob \\ ${ }^{1}$ Department of Social Science and Management, Faculty of Humanities, Management and \\ Science, Universiti Putra Malaysia Bintulu Campus, Malaysia, ${ }^{2}$ Faculty of Business, \\ Economics and Accountancy, Universiti Malaysia Sabah, Malaysia \\ Email: shairil@upm.edu.my
}

\begin{abstract}
Malaysia recorded a fiscal policy with a deficit budget since the economic crisis in 1997. During the tough economic crisis to maintain economic growth, the government committed to stimulus fiscal budget controlling. According to the Keynesian theory, a fiscal policy may induce economic growth at moderate levels of public debt. Although debt and economic growth are not recent issues faced by the Malaysia government, the impact government debt on economic growth has been debated, especially in terms of imbalances development. This work aims to investigate the relationship between economic growth and government debt in Malaysia, with the application of structural break analysis. We utilized econometric techniques such as unit root tests and Granger. Regarding the unit root test, we used structural break combinations with pure and partial structural change models. The analysis is based on data across the period of 1970 to 2018. We find more evidence against the unit root test with structural breaks in Malaysia, with causality between debt and economic growth.
\end{abstract}

Keywords: Debt, Structural Break, Malaysia, Fiscal Policy

\section{Introduction}

Probabilities from fiscal policy with government debt leads to an increase in interest rates, economic stability and impact by foreign investors (Dissou and Nafie, 2021; Tasos, 2012; Georgiou, 2009). Increase government debt has always been in debate among politicians in Malaysia, especially in terms of its implication towards economic growth in the long-run. However, this methodology of fiscal policy may induce economic growth based on the Keynesian theory. In Malaysia, the maximum public debt is 60 percent of the Gross Domestic Product (GDP). According to Bernama (2021), 1 percent of debt from the GDP is equivalent to RM15 Billion. One of the methodologies used is injection of government debt to fiscal policy for a stimulus package, especially during the pandemic crisis in Malaysia in 2020/2021. Malaysia has introduced PRIHATIN, PENJANA and PERMAI stimulus packages as an attempt for economic recovery. Moreover, Tasos (2012) mentioned that lower levels of growth lower public revenue, and increase public expenditure, leading to increase of public debt. However, 
to control the spread of the pandemic and revive the economy, government expenditures can be used as a useful tool (Fu and Chang, 2021). The objective of this study is to identify the relationship between economic growth and government debt. We incorporate in this paper revisit testing for unit roots to compare some of these tests in a simulation study.

\section{Literature Review}

A major debate and continuously increased government debt lead to economic growth or implication to economic sustainability. Imaginário and Guedes (2020) mentioned that there is a positive correlation concerning government debt with levels of institutional and regulatory efficiency of a country, using a sample of 164 countries for the period between 2002 and 2015. Fiscal policy and monetary policies were employed by the government to control economic growth. When tax revenue exceeds government spending, a budget surplus is used to pay down debt.

Potential negative effects of high public debt were already discussed by Nakamura (2017). With specific analysis, the soviet economy shows restricted market activities using Bayesian Markov chain Monte Carlo (MCMC). Soviet economic development was unique and, thus, Soviet institutions and strategies for industrial development are hardly applicable to other economies. The analysis found that the funds supplied to the economy had contributed at a decreasing rate to economic growth. For open economy countries, sustainability in debt can be considered if the rates of GDP increase excess the rates of debt increase (Draksaite et al. 2015). Malaysia implemented prudent and efficient government spending with $56.6 \%$ of debt of GDP, and had an A- rating by Moody's, Fitch Ratings and S\&P Global Ratings (Zanariah, 2020). The rating may have a significant impact towards development economics. Tamegawa (2016) claimed that credit rating to debt-to-GDP ratio leads to economic stability in the sense the ratio with methodology Dynamic Stochastic General Equilibrium (DSGE) mode.

According to Herndon et al (2013), economic growth sharply declines if the public debt reaches a threshold value about $90 \%$ of GDP. In addition, many advanced economies are facing quadruple debt overhang problems. High public debt levels might also affect a government's ability to respond to economic shocks with counter-cyclical fiscal policy. Reinhart et al (2012) mentioned that in the heated debate about the consequences of public debt, the most famous example is possibly on economic development. To boost economic growth and attract foreign investment combination, monetary and fiscal policy are more likely to complement. However, Izumi (2020) claimed that the effectiveness of government guarantees, liquidity regulation and a combination of the two policies in stabilizing the banking system given the negative feedback loop between banks and the government.

\section{Methodology}

In this present work, we applied time series data obtained from the Ministry of Finance Malaysia (MoF) for government debt in Ringgit and GDP per capita from the International Monetary Fund (IMF). The data covers the period 1970 until 2018, with transform to the logarithm. The basic equation for our analysis according model was posed by Georgiou (2009), and we applied a random walk hypothesis in the most common form for examining the relationship between GDP and Debt, as follows:

$$
G D P_{t}=\beta_{0}+\beta_{1}(D e b t)+\mu_{t}
$$

where $\mathrm{GDP}_{\mathrm{t}}$ is the natural logarithm of the Gross Domestic Product (USD) at time t. $\beta_{1}(D e b t)$ is the natural logarithm of a government debt (RM Million) at time $t-1$, and $\mu_{t}$ should be independent and identically distributed random variables. In order of integration of a time 
series data, we use unit a root test. In the terminology of time series, if a time series is stationary, it is said to be integrated of order zero, or I(0) for short (Wang, 2003). However, Lanne and Lutkep (2002) mentioned that many time series have changes in their construction or description that occur at a known point in time, assuming a known shift date is useful. Campbell et al. (1997) use the following notation:

$$
G D P_{t}-\alpha t=\pi\left[\beta_{t-1}(D e b t)-\alpha(t-1)\right]+\mu_{t}, \pi \in(-1,1)
$$

where $\mu_{t}$, is a stationary process and $\mathrm{T}$ is the sample size, as follows:

$$
\sigma_{\mu}^{2}=\lim _{T-\infty} E\left[T^{-1}\left(\sum_{t=1}^{T} \mu_{t}\right)^{2}\right]<\infty
$$

To overcome the stationary problem, traditional unit root tests were employed in this analysis such as those by Dickey-Fuller (1979), Philips and Perron (1988) and Kwiatkowski et al. (1992). The next steps with the structural break unit root test were proposed by Zivot and Andrews (1992) for estimating a shift in the level of the series by including dummy variables into the proposed model. If each of the series means and variances are independent of the time trend, the data is called stationary. Consequently, if a series is non-stationarity, we can assume it has a unit origin. However, Rahman and Saadi (2008) mentioned that while non-stationary is a required prerequisite for the random walk hypothesis, it is not a sufficient condition.

Salahuddin et al. (2019) mentioned that macro time series data are likely to be subjected to a variety of local and external economic shocks over time, hence multiple breaks in such data cannot be ruled out. According to Zivot and Andrews (1992), structural breaks circumvent the problem of data-mining. Three models were used to look for a unit root: Model $A$, which allows for a one-time change in the level of the trend function; Model $B$, which allows for a one-time change in the slope of the trend function, and Model $\mathrm{C}$, which incorporates onetime changes in the level and slope of the trend function. These are defined as follows:

$$
\begin{aligned}
& \Delta Y_{t}=k+\alpha^{*} Y_{t-1}+\beta^{*} t+\theta_{t} D U_{t}+\sum_{j=1}^{k} d_{j} \Delta Y_{t-j}+\varepsilon_{t} \text { (Model A) } \\
& \Delta Y_{t}=k+\alpha^{*} Y_{t-1}+\beta^{*} t+\delta_{t} D T_{t}+\sum_{j=1}^{k} d_{j} \Delta Y_{t-j}+\varepsilon_{t} \text { (Model B) } \\
& \Delta Y_{t}=k+\alpha^{*} Y_{t-1}+\beta^{*} t+\partial_{t} D U_{t}+\delta_{t} D T_{t}+\sum_{j=1}^{k} d_{j} \Delta Y_{t-j}+\varepsilon_{t} \text { (Model C) }
\end{aligned}
$$

where $D U_{t}$ and $D T_{t}$ represent dummy variables occurring at each possible break -date and corresponding trend shift. We employ the last method in the analysis to achieve the objective of study Bai and Perron (2003) for estimating multiple structural break test.

\section{Results and Discussion}

Spurious regression is among the issues in time series analysis. To overcome the problem, we applied a unit root test to identify whether our variables are stationary or non-stationary. The results test for traditional unit root test is presented in Table 1. From the table, all our variables are integrated of order (I). Taasim, Pinjaman, \& Albani (2021) mentioned that asymptotic behavior of the time-series and the cross-sectional dimensions need to be addressed using a unit root test.

Table 1: Unit root estimation results

\begin{tabular}{|l|l|l|l|l|l|l|l|l|l|}
\hline & \multicolumn{4}{|l|}{ At level } & \multicolumn{4}{l|}{ First difference } & \multirow{2}{*}{ Result } \\
\cline { 2 - 10 } & Constant & \multicolumn{4}{l|}{ Trend } & \multicolumn{2}{l|}{ Constant } & \multicolumn{2}{l|}{ Trend } \\
\cline { 2 - 10 } & ADF & PP & ADF & PP & ADF & PP & ADF & PP & \\
\hline Igdp & -2.43 & -2.39 & -2.43 & -2.81 & $-5.29 *$ & $-5.33^{*}$ & $-5.29 *$ & $-5.33^{*}$ & Stationary \\
\hline Idebt & -1.44 & -1.86 & -1.44 & -2.02 & $-3.39 * *$ & $-3.29 * *$ & $-3.39 *$ & $-3.29 *$ & Stationary \\
\hline
\end{tabular}


Significant at $* 1 \%$. $* * 5 \%$

Note: The optimal lag structure of the ADF test was chosen based on the Akaike Information Criterion.

As discussed in methodology section, we employed Zivot Andrew's unit root test with structural break. The break point for GDP is 1997 and DEBT is 1989. In this study, we used dummies DM (1) 1997 for the year of the Financial Crisis, and DM (2) during 1989 the global economy was affected due to the weakening American Economy and oil price shock.

Table 2: Zivot Andrew Test

\begin{tabular}{|l|l|l|}
\hline & t-statistic & Break-point \\
\hline LGDP & $-3.97^{*}$ & 1997 \\
\hline LDEBT & $-3.17^{*}$ & 1989 \\
\hline $1 \%$ critical value & -5.57 & \\
\hline $5 \%$ critical value & -5.08 & \\
\hline $10 \%$ critical value & -4.82 & \\
\hline
\end{tabular}

Significant at $* 1 \%$.

In Table 2, we presented Zivot Andrew test unit root test. From our analysis, we can reject the null hypothesis with the significance at level $1 \%$. The break-point for the variable LGDP is 1997 and LDEBT is 1989. The year of 1997 was the start of the Asian Financial Crisis, and Malaysia was one of the countries that was impacted from this crisis. In 1996, the GDP for Malaysia was almost positive $10 \%$, and this dropped to positive $7.3 \%$ in 1997 . However, at the end of the year 1997/1998, the GDP for Malaysia was -7.3\% (World Bank, 2020). Malaysia was introduced to the east economic policy in 1982. Japan and Korean were especially affected, with a slowdown turn of the East economy. The Japanese Price Bubble greatly affected Japan's Economic, especially the stock index. The impact to GDP growth for Malaysia after the boom of the economy from negative $(-1.02)$ to $9.98 \%$ within 2 years, and shows a gradual drop to $9.06 \%$ in 1989 , the break-point for variable LDEBT.

Table 3: Bai-Perron Breakpoints Test

\begin{tabular}{|l|l|l|l|}
\hline Break Test & F-statistic & Scaled F-statistic & Critical Value** \\
\hline 0 vs. $1^{*}$ & 11.54 & 23.09 & 11.47 \\
\hline 1 vs. $2^{*}$ & 19.22 & 38.44 & 12.95 \\
\hline 2 vs. 3 & 6.80 & 13.61 & 14.03 \\
\hline Chosen number of breaks & 2 & \\
\hline Breaks & 1981 & \\
\cline { 2 - 4 } & 1992 & \\
\hline
\end{tabular}

Significant at *1\%.

The number of chosen of breakpoints in our model is two (2) with breaks years 1981 and 1992. Table 3 presents Bai-Perron breakpoints test with significant critical value at 0.01 .

\section{Conclusion}

In this study, we empirically developed a relationship between economic growth and government debt for the economy of Malaysia. We employed Augmented Dickey-Fulled (1979) test and Phillips-Perron (1988) in testing the stationarity. We used unit roots to 
sensitive structural break to provide little additional evidence against the unit-root hypothesis. Our findings found a significant relationship between government debt and economic growth for Malaysia. Our evidence confirms the financial economic crisis 1997, and the policy implemented by the government, affected economic growth. The economic crash is the major cause of the breaks. The Look East Policy with focusing on this country as a major trading partner according to the government policy in the event of a crisis will affect the national economy. However, the prudence of spending and managing the economy were implemented by the government, showing a beneficial effect on economic growth. This situation Malaysia is able to survive in times of economic crisis.

\section{Acknowledgement}

The author(s) received no financial support for the research, authorship, and/or publication of this article.

\section{References}

Bai, P., \& Perron, P. (2003) Computation and analysis of multiple structural change in models. Journal of Applied Econometrics. Vol.18. 1-22.

Bernama. (2021). Paras siling hutang 60 peratus cukup buat masa ini. Sinar Harian, Retrieved from https://www.sinarharian.com.my/article/109262/BERITA/Nasional/Paras-silinghutang-60-peratus-cukup-buat-masa-ini

Campbell, J. Y., Lo, A. W., \& MacKinlay, A. C. (1997). The econometrics of financial markets. Princeton University Press.

Draksaite, A., Snieska, V., Valodkiene, G., \& Daunoriene, A. (2015). Selection of Government Debt Evaluation Methods Based on the Concept of Sustainability of the Debt. Procedia - Social and Behavioral Sciences, 213, 474-480. https://doi.org/10.1016/j.sbspro.2015.11.436

Dickey, D. A., \& Fuller, W. A. (1979). Distribution of the Estimators for Autoregressive Time Series with a Unit Root. Journal of the American Statistical Association, 74(366), 427. https://doi.org/10.2307/2286348

Dissou, Y., \& Nafie, Y. (2021). On the link between current account and fiscal imbalances in the presence of structural breaks: Empirical evidence from Egypt. The Quarterly Review of Economics and Finance, 79, 15-27. https://doi.org/10.1016/j.qref.2020.12.004

Georgiou, M. N. (2009). Government Debt Impacts on Interest Rates as Well as Entrepreneurship; A Panel Data Analysis for Western Europe, Japan and the United States (1990 - 2006). SSRN Electronic Journal. https://doi.org/10.2139/ssrn.1496319

Fu, Q., \& Chang, C.-P. (2021). How Do Pandemics Affect Government Expenditures? Asian Economics Letters. https://doi.org/10.46557/001c.21147

Herndon, T., Ash, M., \& Pollin, R. (2013). Does high public debt consistently stifle economic growth? A critique of Reinhart and Rogoff. Camb. J. Econ. 38 (2), 257-279, https://doi.org/10.1093/cje/bet075

Imaginário, J., \& Guedes, M. J. (2020). Governance and government debt. Risk Governance and Control: Financial Markets \& Institutions, 10(3), 34-49. http://doi.org/10.22495/rgcv10i3p3

Izumi, R. (2020). Financial stability with sovereign debt. Journal of Financial Stability, 51, 100795. https://doi.org/10.1016/j.jfs.2020.100795

Lanne, M., \& Lutkep, H. (2002) Unit root tests for time series with level shifts: a comparison of different proposals. Economics Letters. Vol. 75. 109-114. 
Lumsdaine, R., \& Papell, D. (1997). Multiple Trend Breaks and the Unit-Root Hypothesis. The Review of Economics and Statistics, 79(2), 212-218. Retrieved March 15, 2021, from http://www.jstor.org/stable/2951453

Nakamura, Y. (2017). The relationship between the real and financial economies in the Soviet Union: An analysis of government debts using newly available data. Explorations in Economic History, 66, 65-84. https://doi.org/10.1016/j.eeh.2017.06.001

Philips, P. C. B., \& Perron, P. (1988). Testing for a unit root in time series regression. Biometrika, 75(2), 335-346. https://doi.org/10.1093/biomet/75.2.335

Rahman, A., \& Saadi, S. (2008). Random walk and breaking trend in financial series: An econometric critique of unit root tests. Review of Financial Economics, 17(3), 204-212. https://doi.org/10.1016/j.rfe.2007.05.002

Reinhart, C. M., Reinhart, V. R., \& Rogoff, K. S. (2012). Public debt overhangs: advancedeconomy episodes since 1800. J. Econ. Perspect. 26 (3), 69-86, https://doi.org/10.1257/jep.26.3.69.

Salahuddin, M., Gow, J., Ali, Md. I., Hossain, Md. R., Al-Azami, K. S., Akbar, D., \& Gedikli, A. (2019). Urbanization-globalization-CO2 emissions nexus revisited: empirical evidence from South Africa. Heliyon, 5(6), e01974. https://doi.org/10.1016/j.heliyon.2019.e01974

Taasim, S. I., Pinjaman, S., \& Albani, A. (2021). Does energy consumption and trade openness contribute to economic growth in the east Asian growth area?. International Journal of Energy Economics and Policy, 11(2), 23-29. https://doi.org/10.32479/ijeep.10644

Tasos, S. (2012). Does Government Debt Promote Economic Growth? An Empirical Analysis with Structural Breaks for the Economy of China. The Romanian Economic Journal. Vol XV (46). 229-248.

Tamegawa, K. (2016). Rating for government debt and economic stability. The Journal of Economic Asymmetries, 13, 35-44. https://doi.org/10.1016/j.jeca.2015.05.003

Wang, P. (2003) Financial Econometric. Routledge Taylor \& Francis Group.

Zanariah, A. B. (2020) Hutang, tanggungan liabiliti negara hujung tahun RM1.264 trillion. https://www.bharian.com.my/berita/nasional/2020/08/720373/hutang-tanggunganliabiliti-negara-hujung-tahun-rm1264-trilion.

Zivot, E., \& Andrews D. (1992), "Further evidence of great crash, the oil price shock and unit root hypothesis", Journal of Business and Economic Statistics, 10, pp 251-270. 